\title{
Optimum Temperature and Time for Acid Hydrolysis in Reducing Sugar Manufacturing from Arabica Coffee Cascara with Response Surface Methodology (RSM)
}

\author{
Suryati, Meriatna, Masrullita, Ferri Safriwardy, Ardiansyah \\ Department of Chemical Engineering, Faculty of Engineering, Universitas Malikussaleh, Aceh Utara, Indonesia \\ *Corresponding Author: suryati@unimal.ac.id
}

Received: 26 March 2021

Revised: 14 April 2021

Accepted: 27 April 2021

\begin{abstract}
This research aims to utilize the Arabica coffee cascara waste as a resource for reducing sugar production, including the investigation on the temperature and time required of the acid hydrolysis. The samples were initially pretreated (drying and milling), followed by delignification with the organosolv technique using alcohol. Then, the hydrolysis was carried out using sulfuric acid $(1 \%)$ at a particular temperature $\left(95,100\right.$, and $\left.105{ }^{\circ} \mathrm{C}\right)$ and time $(2,4$, and $6 \mathrm{~h})$ variations. Yield percentage, density, and reducing concentration were analyzed in each trial to generate a response surface methodology model. Based on the results, the hydrolysis can be optimized at $96.46{ }^{\circ} \mathrm{C}$ for $2.59 \mathrm{~h}$, yielding $16.7696 \%$ reducing sugar.
\end{abstract}

Keywords: cascara; reducing sugar; delignification; hydrolysis; optimization;

\section{Introduction}

There are types of coffee produced in Indonesia; Arabica and Robusta coffee beans. Arabica coffee is a flagship product that is massively marketed. Almost $75 \%$ of the coffee production in the world is Arabica coffee, in which Indonesia contributes 10\% of that percentage. Meanwhile, for Robusta coffee, it is around $25 \%$ of the marketed coffee, where 33\% of that percentage is from Indonesia In 2012, the directorate general of the plantation of Republic of Indonesia recorded that Indonesian coffee plantation has reached 1 million and 300 thousand hectares for Robusta (601 thousand productions) and Arabica coffee (147 thousand productions), respectively

Unprocessed coffee cascara waste can adversely impact the environment, meanwhile, the coffee industry in Indonesia is the largest income contributor as well as the most important in agricultural industry development (Indartono, 2005). The availability of cascara waste is high, where coffee processing produces $65 \%$ coffee bean and 35\% waste. Moreover, Indonesian coffee production, in 2009, was 689 tons.

The production of reducing sugars from lignocellulose has attracted the attention of researchers in recent years. Lignocellulose can be obtained from many sources such as coffee skins, but the use of coffee skins is not optimal because farmers generally sell the waste at low prices for animal feed. (Hutapea, 2017)

Based on the very high coffee production in Central Aceh District, because the demand for Arabica coffee beans is increasing from year to year, the potential for utilizing the coffee bean waste is high enough to produce reducing sugar, known as liquid sugar (Kumalaningsih, 2006). It is firstly necessary to investigate the sugar content within the Arabica coffee cascara to make it applicable for reducing sugar production. Previous researches have not yet succeeded in producing a product with high glucose and standardized characteristics (SNI). Therefore, this research is essential to develop an effective and environmentally friendly hydrolysis process.

\section{Materials and Methods}

This study used a central composite design based on the RSM for optimization. The manufacturing of reducing sugar from the Arabica coffee cascara was conducted based on two observed variables; hydrolysis temperature $\left(95,100\right.$, and $\left.105{ }^{\circ} \mathrm{C}\right)$ and time $\left(2,4\right.$, and $6 \mathrm{~h}$ ). Fixed variables are set at $105{ }^{\circ} \mathrm{C}$ drying temperature, $1 \mathrm{~h}$ drying time, 80-100 mesh powder particle size, 50\% ethanol concentration, and $100 \mathrm{~min}$ delignification time. 


\subsection{Material}

The materials used in this research included coffee Arabica collected from the plantation in Bener Meriah, Aceh Tengah.

\subsection{Research Procedure}

\section{Pre-treatment of coffee cascara}

The cascara was washed clean with distilled water and dried under the sunlight, followed by oven-drying for $24 \mathrm{~h}$ to reach constant weight. The sample was ground to obtain 80-100 mesh powder, followed by delignification with alcohol, and hydrolyzed using sulfuric acid 1\% to yield the reducing sugar.

Delignification (organosolv) of coffee cascara

The powdered coffee cascara was delignified in a three-neck round bottom flasks using $12 \mathrm{~g}$ citric acid and ethanol $50 \%$ at $300 \mathrm{rpm}$ for $2 \mathrm{~h}$. It was then left cold and filtered using filter paper and neutralized using 800 $\mathrm{mL}$ distilled water before drying in an oven at $105^{\circ} \mathrm{C}$.

\section{Sulfuric acid hydrolysis}

The residual powder from the delignification process was put into the reflux flask, $1 \% \mathrm{H} 2 \mathrm{SO} 4$ was added for 2, 4, and 6 hours, respectively. and temperatures of 95, 100, 105 The solution was filtered and neutralized using distilled water, dried in an oven at $105^{\circ} \mathrm{C}$ for 1 hour, and allowed to cool

\section{Preparation of Luff Schrool Solution}

As much as $143.8 \mathrm{~g} \mathrm{Na} 2 \mathrm{CO} 3$ anhydrate was dissolved in 300 distilled water. It was stirred, while added with $50 \mathrm{~g}$ citric acid that had been priorly dissolved in $50 \mathrm{~mL}$ distilled water. Then it was added with $25 \mathrm{~g}$ CuSO4.5H2O had been dissolved in $100 \mathrm{~mL}$ distilled water. The solution was removed into a volumetric flask $1 \mathrm{~L}$, shaken, filtered, and left overnight.

\subsection{Optimization}

For the optimization, this research used the response surface method (RSM), with the purpose of finding an optimum response. RSM is a mathematical and statistical technique that can be used to construct a model and problem analysis, where the response is affected by several variables aiming to optimize the response (Montgomery, 2001). By using RSM, through a research design, mathematical model development, and determination of optimum condition for free variables, ones can obtain the maximum and minimum results of a process. The use of RSM is based on the quadratic polynomial equation that predicts the results of the free variables function as well as their interaction (Wibowo et al., 2019).

\section{Results and Discussions}

The results of this research is the calculation of yield, density, and content of the reducing sugar, obtained from the coffee cascara using the luff schrool method. The next step was the optimization of the hydrolysis to produce reducing sugar using RSM. The research was designed with a central composite design (CCD) with a 13-plots trial. The RSM was constructed using Software Design Expert 11. The parameters (reducing sugar content $(\%)$, yield $(\%)$, and density $\left.\left(\mathrm{g} / \mathrm{cm}^{3}\right)\right)$ affected by the temperature and time are discussed. The use of CCD with the first variable was hydrolysis temperature $(\mathrm{X} 1) ; 95,100$, and $105{ }^{\circ} \mathrm{C}$. The second variable was hydrolysis time $\left(X^{2}\right) ; 2,4$, and $6 \mathrm{~h}$. The response, in a form of reducing sugar content, obtained from the interaction between hydrolysis temperature $\left(X^{1}\right)$ and time $\left(X^{2}\right)$ can be seen in Table 1.

Tabel 1. The Results obtained from the RSM constructed using Software Design Expert 11

\begin{tabular}{cccccc}
\hline Run & $\begin{array}{c}\text { Factor 1 } \\
\text { A: Temperature } \\
\left({ }^{\circ} \mathrm{C}\right)\end{array}$ & $\begin{array}{c}\text { Factor 2 } \\
\text { B: Time } \\
(\mathrm{h})\end{array}$ & $\begin{array}{c}\text { Response 1 } \\
\text { Reducing sugar content } \\
(\%)\end{array}$ & $\begin{array}{c}\text { Response 2 } \\
\text { Density } \\
\left(\mathrm{g} / \mathrm{cm}^{3}\right)\end{array}$ & $\begin{array}{c}\text { Response 3 } \\
\text { Yield } \\
(\%)\end{array}$ \\
\hline 1 & 100.00 & 4.00 & $14.83 \%$ & 0.872 & $21.15 \%$ \\
\hline 2 & 100.00 & 4.00 & $14.83 \%$ & 0.872 & $21.15 \%$ \\
\hline 3 & 103.54 & 5.41 & $12.74 \%$ & 0.986 & $11.60 \%$ \\
\hline 4 & 100.00 & 2.00 & $16.88 \%$ & 0.920 & $32.21 \%$ \\
\hline 5 & 100.00 & 6.00 & $12.76 \%$ & 0.872 & $21.15 \%$ \\
\hline 6 & 100.00 & 4.00 & $14.83 \%$ & 0.952 & $25.01 \%$ \\
\hline 7 & 95.00 & 4.00 & $14.88 \%$ & 0.982 & $15.91 \%$ \\
\hline 8 & 96.46 & 5.41 & $12.84 \%$ & 0.872 & $21.15 \%$ \\
\hline 10 & 100.00 & 4.00 & $14.83 \%$ & 0.872 & $21.15 \%$ \\
\hline 11 & 100.00 & 4.00 & $14.83 \%$ & 0.978 & $27.45 \%$ \\
\hline 12 & 103.54 & 2.59 & $16.73 \%$ & 0.904 & $18.13 \%$ \\
\hline 13 & 105.00 & 4.00 & $14.78 \%$ & 0.972 & $38.84 \%$ \\
\hline
\end{tabular}


Table 2. The ANOVA results for the data obtained from Software Design Expert 11

\begin{tabular}{ccccccc}
\hline Source & Sum of Square & DF & Mean Square & $\begin{array}{c}F \\
\text { Value }\end{array}$ & Prob $>$ F & Information \\
\hline Model & 25.94 & 2 & 12.97 & 119.49 & $<0.0001$ & Significant \\
\hline A & 0.10 & 1 & 0.10 & 0.96 & 0.3511 \\
\hline B & 25.84 & 1 & 25.84 & 238.02 & $<0.0001$ \\
\hline Residual & 1.09 & 10 & 0,11 & & & \\
\hline Lock of Fit & 1.09 & 6 & 0.18 & & \\
\hline Pure eror & 0,000 & 4 & 0,000 & & & \\
\hline Cor Total & 27.02 & 12 & & &
\end{tabular}

The model can be claimed to have a significant impact because the value of the model reached 119.49. There was only $0.01 \%$ possibility, with such $\mathrm{F}$ value, was obtained because of disruption. If the value of the probability (Prob $>$ F) is less than 0.05 , the model is considered significant. However, if the value is higher than 0.1, the model will be referred to as insignificant. ANOVA for the modal and variable A gave a probability value of higher than 0.05 , as shown in Table 2 . It shows that the model is linear and variable A only gave a little effect against the production of reducing sugar. Nonetheless, variable A was still included in the model, because this variable might significantly impact the reducing sugar. In addition, variable B gave a lower value than 0.1 indicating its statistical significance on the reducing sugar content produced.

The response surface graph of reducing sugar content against the interaction factors of temperature $\left(\mathrm{X}_{1}\right)$ and time $\left(\mathrm{X}_{2}\right)$ can be seen in Figure 1.

Figure 1 shows that the lowest reducing sugar content can be produced at $103.54{ }^{\circ} \mathrm{C}$ for $5 \mathrm{~h} 14 \mathrm{~min}$, with the total content of the reducing content is $12.74 \%$. The highest content $(17.40 \%)$ was shown for the hydrolysis at $96.46{ }^{\circ} \mathrm{C}$ for $2 \mathrm{~h} 59 \mathrm{~min}$. Therefore, we can conclude that lower temperature and time can improve the hydrolysis process of the Arabica coffee cascara resulting in high reducing sugar content, and vice versa. It is ascribed to lower temperature preventing further degradation of reducing sugar, allowing higher content percentage. The effect of temperature and time against the yield percentage of reducing sugar can be observed in Figure 2.

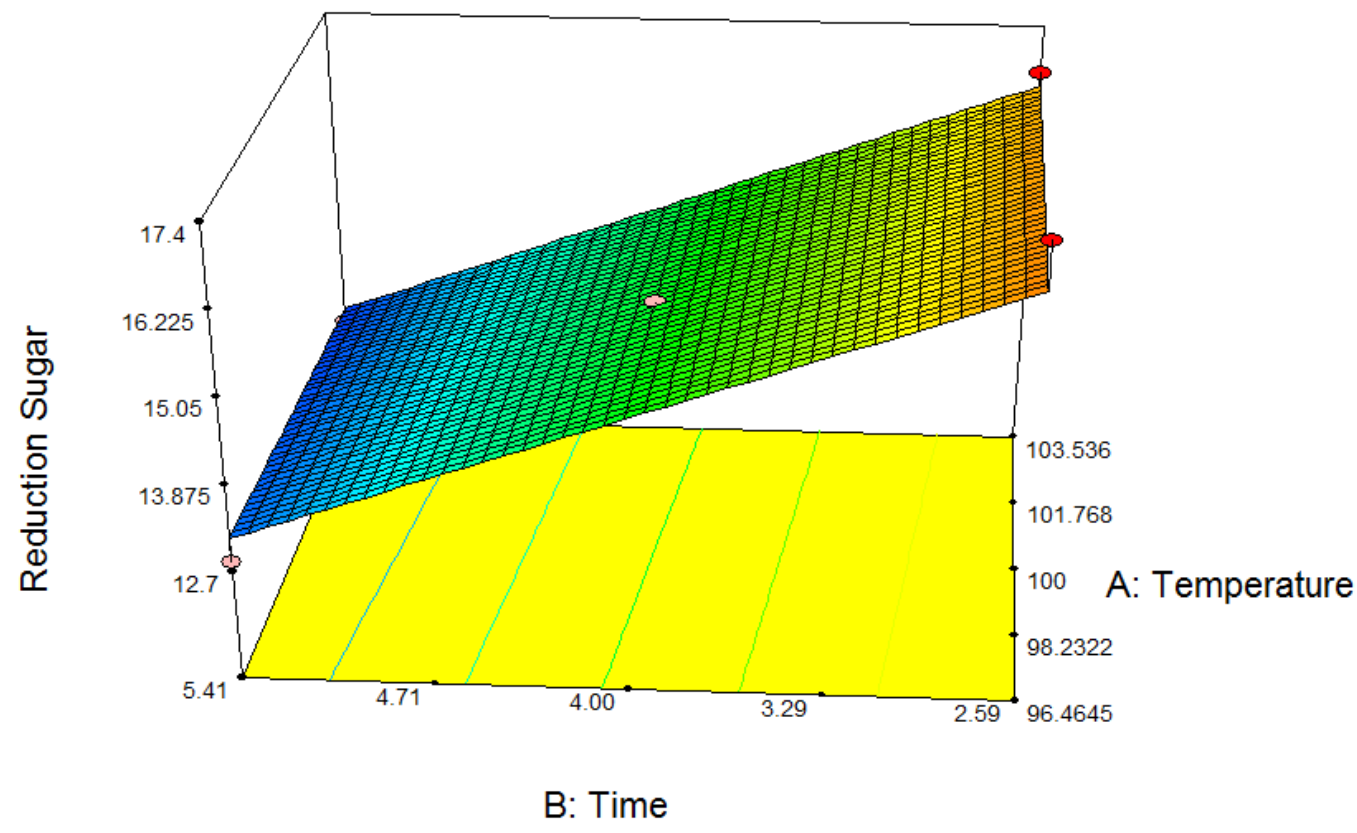

Figure 1. Response surface of the reducing sugar content against the interaction factors of temperature $\left(\mathrm{X}_{1}\right)$ and time $\left(\mathrm{X}_{2}\right)$ 


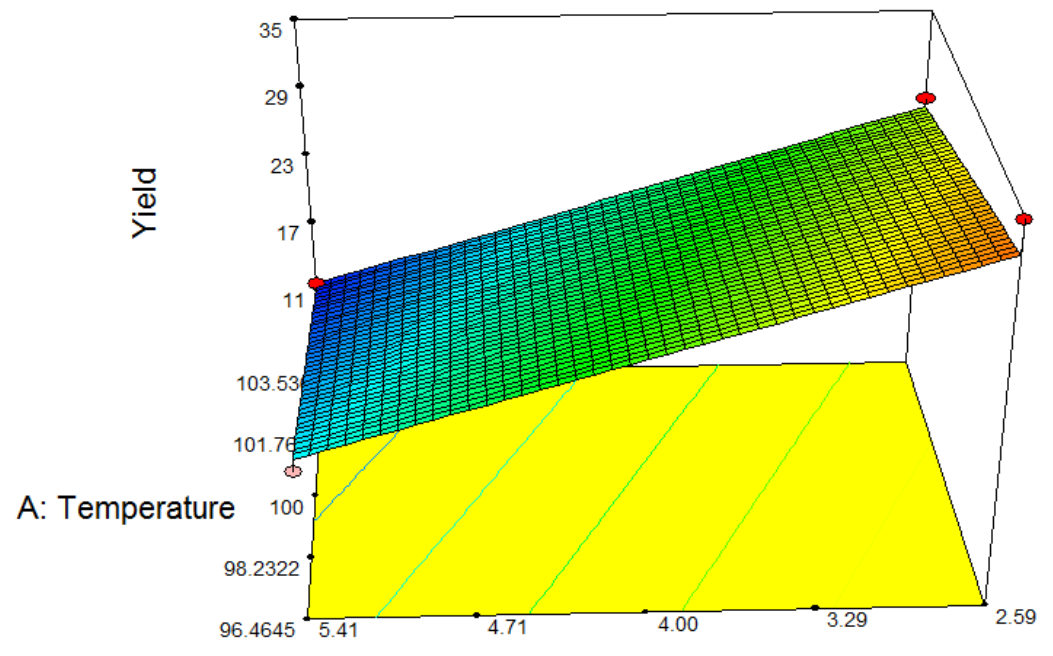

B: Time

Figure 2. The Effect of temperature and time of the hydrolysis against the yield (\%) of the reducing sugar.

Figure 2 shows that the lowest yield percentage (11.60\%) can be produced at $103.54{ }^{\circ} \mathrm{C}$ with $5 \mathrm{~h} 41 \mathrm{~h}$ hydrolysis duration. As for the highest yield $(38.84 \%)$, it can be obtained from the hydrolysis process conducted at $96.46{ }^{\circ} \mathrm{C}$ for $2 \mathrm{~h} 59 \mathrm{~min}$. Similar to previous results, lower hydrolysis temperature and time on the Arabica coffee cascara can produce a higher yield percentage of the reducing sugar and vice versa. In addition to the previous analysis results, the following is the effect of temperature and time against the density $\left(\mathrm{g} / \mathrm{cm}^{3}\right)$ (Figure 3).

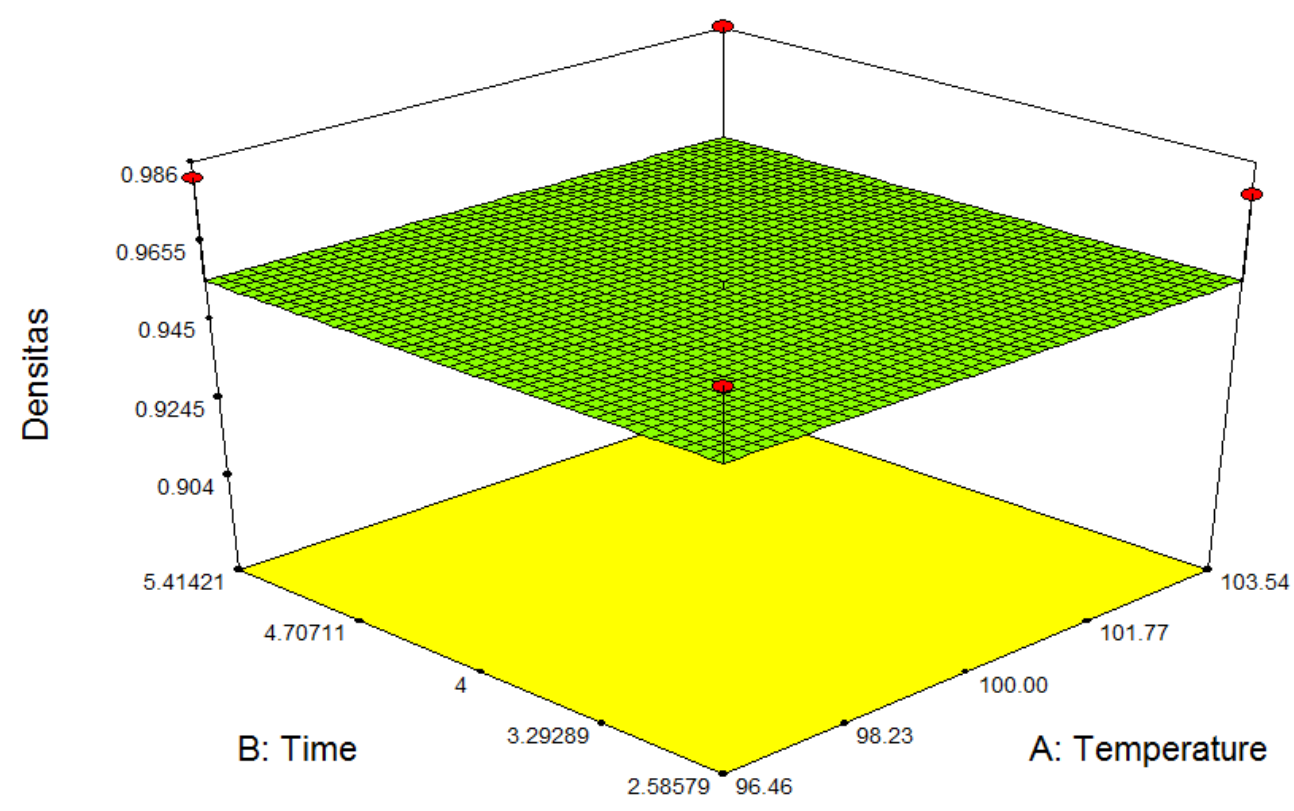

Figure 3. The effect of temperature and time against the density $\left(\mathrm{g} / \mathrm{cm}^{3}\right)$

Figure 3 shows that the density property of the reducing sugar is not changed by the increase or decrease in either temperature or time. It is owing to the fact that the density is not affected by the hydrolysis temperature or time.

The determination of the optimum parameters for each free and fixed variable is based on the data presented in Table 3. 
Table 3. Parameters for the free and fixed variables obtained from the RSM model constructed by Software Design Expert 11.

\begin{tabular}{cccc}
\hline Name & Goal & Lower Limit & Upper Limit \\
\hline Temperature $\left({ }^{\circ} \mathrm{C}\right)$ & in range & 96.5645 & 103.536 \\
\hline Time $(\mathrm{h})$ & in range & 2.58579 & 5.41421 \\
\hline Reducing sugar $(\%)$ & Maximize & 12.74 & 17.40 \\
\hline Yield $\left(\mathrm{g} / \mathrm{cm}^{3}\right)$ & Maximize & 11.60 & 38.84 \\
\hline
\end{tabular}

From the optimization using software design expert 11. It was obtained the optimum values which can be observed in Table 4.

Table 4. Optimum values obtained from the RSM model constructed by Software Design Expert 11.

\begin{tabular}{ccccccc}
\hline No. & $\begin{array}{c}\text { Temperature } \\
(\mathrm{C})\end{array}$ & Time $(\mathrm{h})$ & Reducing Sugar $(\%)$ & Yield $\left(\mathrm{g} / \mathrm{cm}^{3}\right)$ & Desirability & \\
\hline 1 & 96.46 & 2.59 & 16.7695 & 33.4984 & 0.834 & Selected \\
\hline 2 & 97.71 & 2.59 & 16.7294 & 32.3807 & 0.808 \\
\hline
\end{tabular}

Table 5. The experimental results obtained from the optimized variables.

\begin{tabular}{ccccc}
\hline No. & Temperature $\left({ }^{\circ} \mathrm{C}\right)$ & $\begin{array}{c}\text { Time } \\
(\mathrm{h})\end{array}$ & Reducing sugar cotnent $(\%)$ & Yield $\left(\mathrm{g} / \mathrm{cm}^{3}\right)$ \\
\hline 1 & 96.46 & 2.59 & 17.40 & 38.84 \\
\hline
\end{tabular}

Form the optimization, we have successfully identified the combination level of the free variables that give the optimum response, which is the temperature of $96.46^{\circ} \mathrm{C}$ and time of $2.59 \mathrm{~h}$. Meanwhile, the desirability value is 0.834 . The desirability is a functional value indicating the program's ability to satisfy the determined criteria of the end product. The value close to 1 indicates the ability of the program to better produce a good product (Ramadhani, 2017). he purpose of optimization is not to receive desirability of 1, but to identify the best condition that unites all the proposed function (Nurmiah, 2013)

From the analysis, it was obtained $38.84 \%$ yield, $0.972 \mathrm{~g} / \mathrm{cm}^{3}$ density, and $17.49 \%$ reducing content from the coffee cascara. Therefore, the waste material can be potentially utilized as a natural food sweetening agent.

\section{Conclusions}

Based on this research, it can be concluded that the highest reducing sugar content $(17.40 \%)$ was obtained from the first run with a hydrolysis temperature of $96.46^{\circ} \mathrm{C}$ and a time duration of $2 \mathrm{~h} 59 \mathrm{~min}$. The highest yield $(38.84 \%)$ was obtained from the first run, with the aforementioned hydrolysis temperature and time duration. Therefore, the temperature of $96.46^{\circ} \mathrm{C}$ and time duration of $2 \mathrm{~h} 59 \mathrm{~min}$ are considered as the optimum hydrolysis condition; proven by the response received from the RSM analysis. The desirability of this combination was recorded at 0.834 .

\section{Acknowledgement}

The authors would like to thank and appreciate the funding from Dana Pendapatan Negara Bukan Pajak (PNBP) in Daftar Isian Pelaksanaan Anggaran (DIPA) of Universitas Malikussaleh Year 2020. The authors also would like to thank the LPPM Universitas Malikussaleh for their support during the research and the making of this article.

\section{References}

Anindita Dyah Palupi, Herry Purnama, (2020), Pengaruh Ukuran Partikel dan Metode Hidrolisis pada Pembuatan Bioetanol dari Limbah Kulit Kopi Arabika, Proceeding The 11th University Research Colloquium, Universitas Aisyiyah Yogyakarta, p.207-214.

Athiyamaan, V., \& Ganesh, G. M. (2017, November). Statistical and detailed analysis on fiber reinforced selfcompacting concrete containing admixtures-A state of art of review. In IOP Conference Series: Materials Science and Engineering (Vol. 263, No. 3, p. 032037). IOP Publishing. 
Badan Standarisasi Nasional. (2010). SNI 3140.3:2010 - Gula kristal - Bagian 3 : Putih. SNI (Standar Nasional Indonesia), ICS 67.180, 1-17.

Hartati, \& Syamsiah. (2010). Analisis Kadar Glukosa Pada Tepung Umbi Amorphophallus sp. (Analysis of Glucose Levels in Tuber Flour Amorphophallus sp.).

Indartono, C. B. R. (2005). Studi teknik produksi gula reduksi dari limbah kulit buah kopi study of reducing sugar production technique from coffee pulp waste ( Parchment Hull/Endocarp).

Kefale, A., Redi, M., \& Asfaw, A. (2012). Potential of bioethanol production and optimization test from agricultural waste: the case of wet coffee processing waste (pulp). Int J Renew Energy Res, 2(3), 446-450.

Kalengkongan, C., Pontoh, J., \& Fatimah, F. (2013). Hubungan antara Beberapa Kriteria Kualitas dengan Warna Gula Aren (Arenga Pinnata Merr.). Jurnal Ilmiah Sains, 13(2), 86-92.

Kumalaningsih, K. P. (2006). jurnal integrasi proses Website: http://jurnal.untirta.ac.id/index.php/jip pembuatan glukosa dari kulit pisang kepok (musa paradisiaca 1 ) dengan proses hidrolisis 1 Program Studi Teknik Kimia, Fakultas Teknik Universitas Mulawarman.

Lumoindong, F., \& Mamuaja, C. F. (2016). Produksi Gula Cair dari Limbah Selulosik sebagai Alternatif Pengganti Cairan Infus. J. Ilmu Dan Teknologi Pangan, 4(1), 36-43.

Mukti, K. S., Rohmawati, N., \& Sulistiyani, S. (2018). Analisis Kandungan Karbohidrat, Glukosa, Dan Uji Daya Terima Pada Nasi Bakar, Nasi Panggang, Dan Nasi Biasa. Jurnal Agroteknologi,

Lai Shan Jin, Midhat Nabil Salimi, and Syazni Zainul Kamal, (2019), Optimization of Pretreatment and Enzymatic Hydrolysis of Spent Coffee Ground for the Production of Fermentable Sugar, 1st International Conference Functional and Engineering Materials - FEM 2019, IOP Conf. Series: Materials Science and Engineering.

Luluk Edahwati, Dyah Suci Perwitasari, Nana Dyah Siswati, (2014), Penurunan Lignin Kulit Buah Kopi dengan Metode Organosolve Reduction of Lignin from Coffee Husk using Organosolve Method, Eksergi, Vol XI, No. 02. 2014, ISSN: 1410-394X.

Prastowo Akbar Hidayat Putra, Herry Purnama, (2019), Pengaruh Waktu Pengeringan Dan Rasio Bahan Baku/Starter Zymomonas Mobilis Pada Pembuatan Bioetanol Dari Limbah Kulit Kopi Robusta, Simposium Nasional RAPI XVIIII - 2019 FT UMS, ISSN 1412-9612.

Murni, Fahmi A, Zainal A, (2014), Optimasi Proses Bioetanol Dari Kulit Kopi Dengan Menggunakan Proses Hidrolisis Vibrous Bed Reaktor, Traksi vol.15 No.1 Eksergi, Vol XI, No. 02, p. ISSN: 1410-394X

Nurmiah, (2012), Pembuatan Bioetanol dari Limbah Kulit Kopi Arabika dan Robusta dengan Variasi Waktu Fermentasi, University Research Colloquium 2020, Universitas ‘Aisyiyah Yogyakarta, p.220-229.

Ramadahni, Q. A. K. (2017). Fakultas Teknik-Universitas Wahid Hasyim Semarang 1. Inovasi Teknik Kimia,

Hutapea, Christa Bella R and Sitorus, Romida Evannita (2017) Studi Teknik Produksi Gula Reduksi dari Limbah Kulit Buah Kopi (Parchment hull/endocarp). Undergraduate thesis, Institut Teknologi Sepuluh Nopember.

Tayyab, M, Noman, A, Islam, W, Waheed, S, Arafat, Y, Ali, F, Zaynab, M, Lin, S, Zhang, H, Lin, W, (2018), Bioethanol Production From Lignocellulosic Biomass By Environment-Friendly Treatment Methods: A Review, Applied Ecology And Environmental Research 16(1):225-249.

Wibowo, Q. A. K. (2019). Fakultas Teknik-Universitas Wahid Hasyim Semarang 1. Inovasi Teknik Kimia. 